\title{
SCIENTIFic Article \\ Growth and nutrients content of heliconia under mineral fertilization
}

\author{
Ariadna Linares-Gabriel ${ }^{1}$; Armando Guerrero-Peña ${ }^{2}$; Mario Alejandro Hernández-Chontal ${ }^{1 *}$; \\ Gloria Esperanza De Dios-León ${ }^{3}$; Nereida Rodríguez-Orozco ${ }^{4}$
}

\begin{abstract}
Heliconias have great commercial importance due to their durability of inflorescences, sizes, forms and bright colors. Regarding its production, the mineral nutrition of the crop is one of the most relevant aspects to obtain quality floral stems. The objective was to determine the influence of N-P-K on the growth and nutritional content of Heliconia stricta Dwarf Jamaican. A completely randomized block design was used with four treatments and five repetitions. The treatments consisted in fertilizing the soil with N-P-K. The levels of fertilization expressed in $\mathrm{kg} \mathrm{ha}^{-1}$ of NPK were: control without application 00-00-00 (T100), 31-31-31 (T231), 62-62-62 (T362) and 93-93-93 (T493). The plants received the treatments for six months. Growth variables and nutrient contents of heliconia biomass were evaluated. The analysis of variance showed significant statistical differences $(P \leq 0.05)$ in the vigor and color of the plant, as well as the phosphorus, magnesium and copper contents. The significant increases in vigor and color were with doses $31-$ 31-31 and 62-62-62 of NPK. As for the contents of P, $\mathrm{Mg}$ and $\mathrm{Cu}$ were influenced by doses 31-31-31, 62-62-62 and 93-93-93 of NPK. This work shows important findings in relation to the nutritional diagnosis in the foliar content of nutrients.
\end{abstract}

Keywords: Heliconia stricta Dwarf Jamaican, tropical flowers, plant nutrition, production, commercial quality.

\section{Resumo}

\section{Crescimento e estado nutricional de heliconia sob fertilização mineral}

Heliconias têm grande importância comercial devido à durabilidade de suas inflorescências, tamanhos, formas e cores brilhantes. Em relação à sua produção, a nutrição mineral da cultura é um dos aspectos mais relevantes para a obtenção de hastes florais de qualidade. O objetivo foi determinar a influência do N-P-K no crescimento e estado nutricional de Heliconia stricta Dwarf Jamaican. O delineamento experimental utilizado foi o inteiramente casualizado com quatro tratamentos e cinco repetições. Os tratamentos consistiram na fertilização do solo com N-P-K. Os níveis de adubação expressos em $\mathrm{kg} \mathrm{ha}^{-1}$ de NPK foram: controle sem aplicação 00-00-00 (T100), 31-31-31 (T231), 62-62-62 (T362) e 93-93-93 (T493). As plantas receberam os tratamentos por seis meses. Variáveis de crescimento e teores de nutrientes da biomassa de helicônia foram avaliadas. A análise de variância mostrou diferenças estatisticamente significativas $(P \leq 0.05)$ no vigor e na cor da planta, assim como para os teores de fósforo, magnésio e cobre. Os aumentos significativos no vigor e cor foram com as doses 31-31-31 e 62-62-62 do NPK. Quanto ao conteúdo de P, Mg e $\mathrm{Cu}$, esses foram influenciados pelas doses 31-31-31, 62-62-62 e 93-93-93. Este trabalho mostra importantes achados em relação ao diagnóstico nutricional no teor foliar de nutrientes.

Palavras-chave: Heliconia stricta Dwarf Jamaican, flores tropicais, nutrição vegetal, produção, qualidade comercial.

\section{Introduction}

Heliconia stricta 'Dwarf Jamaican' along with other cultivars have great commercial importance due to their durability of inflorescences and bright colors (Cantor et al., 2014). In relation to its production, the application of synthetic fertilizers represent a significant percentage of production costs (Al- buquerque et al., 2010), which translates into high amounts of nitrogen, phosphorus, potassium and magnesium, iron, manganese and organic material (Matos-Viégas et al., 2014).

Concerning the functions of the three main macronutrients, nitrogen is an important component of all proteins and nucleotide acids; it is also present in coenzymes, nucleotides, amides, ureides, in chlorophyll, among others.

\footnotetext{
${ }^{1}$ Colegio de Postgraduados - Campus Veracruz, Postgrado en Agroecosistemas Tropicales, Veracruz, México. *Corresponding author: hernandez. chontal@gmail.com

${ }^{2}$ Colegio de Postgraduados - Campus Tabasco, Postgrado en Producción Agroalimentaria en el Trópico, Tabasco, México.

3 Universidad Veracruzana, Facultad de Ciencias Biológicas y Agropecuarias - Peñuela, Veracruz, México.

${ }^{4}$ Universidad Veracruzana, Facultad de Ciencias Agrícolas - Xalapa, Veracruz, México.
} 
Phosphorus is part of the nucleic acids and participates in the synthesis of proteins, as a constituent of ATP and many coenzymes and intervenes in all metabolic processes of energy transfer. Potassium is an activator or cofactor of more than 50 enzymes of the metabolism of carbohydrates and proteins, also participates in the ionic balance and osmotic regulation (Alcántar González et al., 2007).

Moreover, in the nutrition of heliconia and species of the order Zingiberales, nitrogen and phosphorus significantly increases the parameters of vegetative growth, flowering and yield in number of floral stems $\mathrm{m}^{2}$ (Patel et al., 2017). Potassium affects the performance of the floral stem and the content of $\mathrm{P}, \mathrm{K}, \mathrm{Ca}$ and $\mathrm{Mg}$ in leaves, besides the increase in the doses of $\mathrm{K}_{2} \mathrm{O}$ in the soil cause a reduction in the $\mathrm{P}$ content of the leaves (Beckmann-Cavalcante et al., 2016). In general, N, P and $\mathrm{K}$ improve the vegetative growth and yield of floral stems and rhizomes (Goh et al., 2018)

In this ornamental species, fertilizers are required to be applied in correct doses (Stewart et al., 2005) and distributed or adjusted to the requirements of the plant in each phase of growth and development (Gowda et al., 1988). Since high amounts are sometimes applied to achieve higher yield (Sushma et al., 2013), it is also necessary to define the moment of application of fertilizers (Taniguchi et al., 2016). All of the above conditions are essential to obtain commercial quality flower stems (Ruppenthal and Castro, 2005).

During this research, low doses of fertilization were applied based on other researches that state the possibility of the nutrient cycle could reduce the entry of fertilizer, reducing production costs and the environmental risks associated with its unnecessary application (Taniguchi et al., 2016). The application of chemical fertilizer can be considered as a complement to the application of organic fertilizers: in this way satisfy the nutritional requirements of the crop minimizing production costs and reducing the environmental impact (Linares-Gabriel et al., 2017; Linares-Gabriel et al., 2018).

Finally, this work contributes to generate information about mineral nutrition of ornamental plants, especially tropical species, because it is considered limited (Merida et al., 2017) therefore, the objective of this research was to determine the influence of the application of N-P-K in the growth and nutrients content of heliconia (Heliconia stricta Dwarf Jamaican).

\section{Materials and Methods}

\section{Location}

Research was conducted under nursery conditions: from February-August 2016 in an experimental site located in the town of Almagres, Municipality of Sayula de Alemán, Veracruz, Mexico. It is located between the coordinates $17^{\circ} 48^{\prime} 53^{\prime \prime} \mathrm{S}$ and $94^{\circ} 56^{\prime} 33^{\prime \prime} \mathrm{W}$ : altitude of 40 meters above sea level. It presents a subhumid warm climate $\left(\mathrm{Aw}_{2}\right)$ according to (García, 1998): precipitation and average temperature of $1750 \mathrm{~mm}$ and $25^{\circ} \mathrm{C}$ respectively.

\section{Soil characteristics}

The soil was collected and analyzed. According to the analyzes performed, the soil showed the following characteristics: $\mathrm{pH} 5.47$, electrical conductivity $879 \mu \mathrm{S} \mathrm{cm}^{-1}$, organic matter $32.25 \%$, total nitrogen $1.08 \%$, phosphorus $59.45 \mathrm{mg} \cdot \mathrm{kg}^{-1}$, potassium $3.12 \mathrm{cmol} \mathrm{kg}^{-1}$, and clay-sandy texture. An average of $3.75 \mathrm{~kg}$ of soil per pot was used.

\section{Crop management}

In order to avoid damage caused by direct exposure of the crop to the Sun, 70 percent shade mesh was placed before sowing. The rhizomes were harvested and a pseudostem cut was made in the upper part to leave it at a length of $20 \mathrm{~cm}$. Very long and dead roots were eliminated. Finally, the rhizome was immersed in a solution of Captan (1 $\mathrm{g} \mathrm{L}^{-1}$ ) in the basal part where the cut was made. After that, sowing was carried out. Two rhizomes were placed in the center of each pot at $10 \mathrm{~cm}$ depth. Three times per week irrigation was carried out in all the treatments: using tap water. The planting distance was $1.5 \times 1 \mathrm{~m}$, considering a population density of 6,060 plants $\mathrm{ha}^{-1}$. This was done in polyethylene bags with a size of $40 \times 40 \mathrm{~cm}$.

\section{Experimental design and treatments}

A completely randomized block design was used with four treatments and five repetitions. The treatments consisted of fertilizing the soil with N-P-K. The levels of fertilization expressed in $\mathrm{kg} \mathrm{ha}^{-1}$ of N-P-K were: control without application 00-00-00 (T100), 31-31-31 (T231), 62-62-62 (T362) and 93-93-93 (T493). The source of fertilizer was triple 17 . The application was made by depositing the fertilizer at a depth of $5 \mathrm{~cm}$ at a distance of $10 \mathrm{~cm}$ from the plant, distributed in six applications from sowing, during the duration of the experiment. In total the following doses g plant ${ }^{-1}$ of N-P-K were applied: 00-00-00, 05-05-05, 1010-10 and 15-15-15 respectively for each treatment. Applications of the same dose were made every month. The experimental unit consisted of a plant.

\section{Variables evaluated}

The variables evaluated were height of the plant, health, vigor, color, number of leaves, leaf area, number of rhizomes and the content of macro and micro nutrients at 210 days after sowing (DAS). The height of the plant (cm) was measured from the base of the plant to the highest leaf. Plant health, vigor and color were evaluated according to Linares-Gabriel et al. (2017). The health was determined with a qualitative scale of ranges from 1-5: where 1 is $100 \%$ or plant insane and 5 is $0 \%$ or healthy plant. The vigor of the plant was determined with a qualitative scale of ranges from 1-5: where 1 is the weak plant and 5 is a vigorous plant. The color of the plant was measured based on the color chart Munsell Color Charts for Plant Tissues ${ }^{\circledR}$ (Munsell, 1952): A scale of 1 was used for yellow, 2 green yellow, 3 green and 4 very green; considering section 2.5 GY (green-yellow). The length and width of the highest leaf of a plant multiplied by 0.74 determined the leaf area $\left(\mathrm{cm}^{2}\right)$ according to Farias et al. (2013). Finally, the number of rhizomes per mat was counted. 
Additionally, the plants were harvested by cutting $5 \mathrm{~cm}$ from the base of the soil in order to determine the content of macro and micronutrients. Leaves and stems were washed separately with distilled water. Subsequently, they were placed in paper bags and put into a forced air oven at 60 ${ }^{\circ} \mathrm{C}$ to obtain constant weight. Last of all, they were ground with a $2 \mathrm{~mm}$ screen. The variables of the plant material were estimated as follows: dry weight in leaf and stem (g) with the formula $=($ wet biomass $* \% \mathrm{DM}) / 100$, nitrogen $(\mathrm{N} \%)$ $=$ modified Kjeldahl micro to include nitrates. Phosphorus $(\mathrm{P} \%)$ and potassium $(\mathrm{K} \%)$ were measured in the digested with $\mathrm{HNO}_{3} / \mathrm{HClO}_{4}$ : the quantification of phosphorus with $\mathrm{UV}$-visible spectrophotometer and potassium by atomic absorption spectrometry. Calcium (Ca\%), magnesium $\left(\mathrm{Mg}^{\circ}\right)$, sodium $(\mathrm{Na} \%)$, iron (Fe: $\left.\mathrm{mg} \mathrm{kg}^{-1}\right)$, copper $\left(\mathrm{Cu}: \mathrm{mg} \mathrm{kg}^{-1}\right)$, zinc (Zn: $\mathrm{mg} \mathrm{kg}^{-1}$ ) and manganese ( $\mathrm{Mn}: \mathrm{mg} \mathrm{kg}^{-1}$ ) was determined using a UV-visible spectrophotometer and by atomic absorption spectrometry. The corresponding analyzes were carried out in the Agroindustrial, Soil, Plant and Water Laboratory (ASPWL) of Colegio de Postgraduados, Campus Tabasco.

\section{Statistical analysis}

The analysis of the variables determined the significance of the individual effects. Square root transformations were made to the qualitative variables of the original data: leaf number, vigor, color, number of rhizomes, health and for nutrients that are determined in percentages. For the analysis of variance, a completely randomized design was applied and the comparison of means with Tukey $(P$ $\leq 0.05)$ through the statistical package Statistical Analysis System (SAS, 2014).

\section{Results and Discussion}

\section{Growth variables}

Significant statistical differences were found $(P \leq 0.05)$ for the variables color and vigor of the plant (Table 1). According to the means test with Tukey $(P \leq 0.05)$ : the best treatments were T231, T362 and T493 with application of fertilizer for both variables (Table 2).

Table 1. Analysis of variance of growth variables evaluated in Heliconia stricta Dwarf Jamaican

\begin{tabular}{|c|c|c|c|c|c|c|c|}
\hline & Height & Leaf area & $\begin{array}{c}\text { Number of } \\
\text { rhizomes }\end{array}$ & $\begin{array}{c}\text { Number of } \\
\text { leaves }\end{array}$ & Health & Vigor & Colour \\
\hline $\begin{array}{c}\text { Levels of } \\
\text { significance }\end{array}$ & $0.7049^{*}$ & 0.4159 & 0.2781 & 0.3083 & 0.2132 & 0.0185 & 0.0007 \\
\hline $\begin{array}{c}\text { Coefficient of } \\
\text { variation }\end{array}$ & $8.55 \%$ & $17.58 \%$ & $10.63 \%$ & $6.18 \%$ & $12.64 \%$ & $9.72 \%$ & $10.71 \%$ \\
\hline
\end{tabular}

$* \mathrm{P} \geq 0.05$, not significant.

Table 2. Comparison of means for growth variables in Heliconia stricta Dwarf Jamaican

\begin{tabular}{|c|c|c|c|c|c|c|c|}
\hline Treatments & $\begin{array}{c}\text { Height } \\
\mathbf{( c m )}\end{array}$ & $\begin{array}{c}\text { Leaf area } \\
\mathbf{( c m )}\end{array}$ & $\begin{array}{c}{ }^{\mathbf{1}} \text { Number of } \\
\text { rhizomes }\end{array}$ & $\begin{array}{c}{ }^{\mathbf{1}} \text { Number of } \\
\text { leaves }\end{array}$ & ${ }^{1}$ Health & ${ }^{1}$ Vigor & ${ }^{\mathbf{1} C o l o u r}$ \\
\hline T231 & $38.4 \mathrm{a}$ & $281.2 \mathrm{a}$ & $14.8 \mathrm{a}$ & $6.4 \mathrm{a}$ & $3.2 \mathrm{a}$ & $3.8 \mathrm{a}$ & $3.6 \mathrm{a}$ \\
\hline T362 & $41.3 \mathrm{a}$ & $256.8 \mathrm{a}$ & $15.4 \mathrm{a}$ & $6.4 \mathrm{a}$ & $3.2 \mathrm{a}$ & $3.6 \mathrm{a}$ & $3.4 \mathrm{a}$ \\
\hline T493 & $41.6 \mathrm{a}$ & $310.9 \mathrm{a}$ & $18.6 \mathrm{a}$ & $6.4 \mathrm{a}$ & $3.4 \mathrm{a}$ & $3.6 \mathrm{a}$ & $3.8 \mathrm{a}$ \\
\hline T100 & $42.0 \mathrm{a}$ & $295.4 \mathrm{a}$ & $13.6 \mathrm{a}$ & $6.9 \mathrm{a}$ & $2.4 \mathrm{a}$ & $2.4 \mathrm{~b}$ & $1.4 \mathrm{~b}$ \\
\hline +HSD & 6.5597 & 94.467 & 0.7839 & 0.2962 & 0.4104 & 0.331 & 0.3442 \\
\hline
\end{tabular}

Means with the same letter within each column do not differ statistically (Tukey, $P \leq 0.05$ )

${ }^{+}$Honestly significant difference

${ }^{1}$ Original means; data transformed according to $\sqrt{ } \mathrm{X}$

The results showed that in low doses of fertilization both variables respond positively in the growth of heliconia (Heliconia stricta Dwarf Jamaican). Some authors, such as Linares-Gabriel et al. (2017) agree on the same findings as they also used low doses in their research work (15 g plant $^{-1}$ of chemical fertilizer). Other authors have used higher dos- es such as Matos-Viégas et al. (2014) and Albuquerque et al. (2010) have applied from 50 to 150 g plant $^{-1}$ of formula 15-15-15 of N-P-K; considering the fact that a significant part of the nutrients applied in the field is not absorbed by the plants and is lost by leaching, volatilization, nitrification or other forms. Such loss increases the cost of fertilizer 
and seriously pollutes the environment (Timilsena et al., 2015).

Furthermore, the supply of nutrients in low doses contributes to a better appearance of the plants of Heliconia stricta Dwarf Jamaican as it is reflected in this study. According to the Ferreira and Oliveira (2003) approach, the application of N-P-K in field conditions favors the productivity of Heliconia $c v$. Golden Torch. The idea that nutrient contents are sometimes determined by biotic and abiotic factors is not excluded; these factors involve temperature, relative humidity, luminosity, genotype, concentration of nutrients in the soil, cultivation and management of the crop (Jarvan and Poldma, 2004).

Concerning the fertilization and management conditions in this study, the vigor of the plants in relation to the control was improved. The application of doses 31-31-31 (T231) of NPK was sufficient. However, it is important to consider the type of substrate exploited to avoid excessive use of chemical fertilizers and consider organic fertilizers as a complement. According to Carvalho et al. (2012) the plants of Heliconia $c v$. Golden Torch exhibit a fairly homogeneous and vigorous growth without visual symptoms of nutritional deficiency; hence, evidencing that the chemical fertilization associated with bovine manure (organomineral) is the most recommended for cultivation.

\section{Nutrients content}

Significant statistical differences were found $(P \leq 0.05)$ for the variables magnesium, phosphorus and copper (Table 3$)$. According to the means test with Tukey $(P \leq 0.05)$, the best treatment for magnesium was T493, for phosphorus were T231 and T362 and for copper the treatments that stood out were T231, T493 and T100 (control without fertilizer application) (Table 4).

Table 3. Analysis variance of nutrients content evaluated in Heliconia stricta Dwarf Jamaican.

\begin{tabular}{|c|c|c|c|c|c|c|c|c|c|c|c|}
\hline & \multicolumn{11}{|c|}{ Treatments } \\
\hline & $\begin{array}{l}\mathrm{N} \\
\%\end{array}$ & $\begin{array}{l}\mathbf{P} \\
\%\end{array}$ & $\begin{array}{l}\mathbf{K} \\
\%\end{array}$ & $\begin{array}{l}\mathrm{C} \\
\%\end{array}$ & $\begin{array}{l}\mathrm{Mg} \\
\%\end{array}$ & $\begin{array}{l}\mathrm{Na} \\
\%\end{array}$ & $\begin{array}{c}\text { Fe } \\
\mathrm{mg} \mathrm{kg}^{-1}\end{array}$ & $\begin{array}{c}\mathrm{Cu} \\
\mathrm{mg} \mathrm{kg}^{-1}\end{array}$ & $\begin{array}{c}\mathrm{Zn} \\
\mathrm{mg} \mathrm{kg}^{-1}\end{array}$ & $\begin{array}{c}\text { Mn } \\
\text { mg kg }^{-1}\end{array}$ & ${ }^{1} \mathbf{D M} \mathrm{g}$ \\
\hline $\begin{array}{l}\text { Levels of } \\
\text { significance }\end{array}$ & $0.0800^{*}$ & 0.0044 & 0.8898 & 0.4466 & 0.0019 & 0.6408 & 0.5678 & 0.0419 & 0.1703 & 0.0662 & 0.6232 \\
\hline $\begin{array}{l}\text { Coefficient } \\
\text { of variation }\end{array}$ & $2.58 \%$ & $5.60 \%$ & $10.88 \%$ & $6.21 \%$ & $3.19 \%$ & $9.27 \%$ & $49.35 \%$ & $7.62 \%$ & $6.83 \%$ & $41.51 \%$ & $30.05 \%$ \\
\hline
\end{tabular}

${ }^{1}$ Dry matter

$* \mathrm{P} \geq 0.05$, not significant.

Table 4. Comparison of means for nutrients content analyzed in Heliconia stricta Dwarf Jamaican.

\begin{tabular}{|c|c|c|c|c|c|c|c|c|c|c|c|}
\hline & \multicolumn{11}{|c|}{ Treatments } \\
\hline & $\begin{array}{l}{ }^{2} \mathbf{N} \\
\%\end{array}$ & $\begin{array}{l}{ }^{2} \mathbf{P} \\
\%\end{array}$ & $\begin{array}{l}{ }^{2} \mathbf{K} \\
\%\end{array}$ & $\begin{array}{c}{ }^{2} \mathrm{Cal} \\
\%\end{array}$ & $\begin{array}{c}{ }^{2} \mathrm{Mg} \\
\%\end{array}$ & $\begin{array}{c}{ }^{2} \mathrm{Na} \\
\%\end{array}$ & $\begin{array}{c}\text { Fe } \\
\mathrm{mg} \mathrm{kg}^{-1}\end{array}$ & $\begin{array}{c}\mathrm{Cu} \\
\mathrm{mg} \mathrm{kg}^{-1}\end{array}$ & $\begin{array}{c}\mathrm{Zn} \\
\mathrm{mg} \mathrm{kg}^{-1}\end{array}$ & $\begin{array}{c}\text { Mn } \\
\mathrm{mg} \mathrm{kg}^{-1}\end{array}$ & ${ }^{1} \mathrm{DM} \mathrm{g}$ \\
\hline $\mathrm{T} 231$ & $2.7 \mathrm{a}$ & $0.4 \mathrm{ab}$ & $0.6 \mathrm{a}$ & $0.8 \mathrm{a}$ & $0.2 b$ & $0.06 \mathrm{a}$ & $286.4 \mathrm{a}$ & $16 a b$ & $28.1 \mathrm{a}$ & $479.3 \mathrm{a}$ & $22.4 \mathrm{a}$ \\
\hline T362 & $2.9 a$ & $0.5 \mathrm{a}$ & $0.5 \mathrm{a}$ & $0.8 \mathrm{a}$ & $0.2 b$ & $0.06 \mathrm{a}$ & $235.9 a$ & $13.5 b$ & $30.1 \mathrm{a}$ & $83.7 \mathrm{a}$ & $32.1 \mathrm{a}$ \\
\hline T493 & $2.4 \mathrm{a}$ & $0.2 \mathrm{c}$ & $0.6 \mathrm{a}$ & $0.8 \mathrm{a}$ & $0.3 a$ & $0.07 \mathrm{a}$ & $240 \mathrm{a}$ & $17 \mathrm{a}$ & $26.4 \mathrm{a}$ & $416.4 \mathrm{a}$ & $29.4 \mathrm{a}$ \\
\hline $\mathrm{T} 100$ & $2.6 \mathrm{a}$ & $0.3 b c$ & $0.5 \mathrm{a}$ & $0.9 a$ & $0.2 b$ & $0.07 \mathrm{a}$ & $414.1 \mathrm{a}$ & $17.7 \mathrm{a}$ & $25.6 \mathrm{a}$ & $362.5 \mathrm{a}$ & $27.8 \mathrm{a}$ \\
\hline${ }^{+} \mathrm{HSD}$ & 0.11 & 0.10 & 0.24 & 0.16 & 0.04 & 0.06 & 410.3 & 3.474 & 5.33 & 393.6 & 23.75 \\
\hline
\end{tabular}

Means with the same letter within each column do not differ statistically (Tukey, $P \leq 0.05$ ).

${ }^{1}$ Dry matter

${ }^{2}$ Original means; data transformed according to $\sqrt{X}$

${ }^{+}$Honestly significant difference

Principally, this research focus on the aspects of the nutritional requirements of the Heliconia stricta which have not been exhaustively studied and for this reason, there is scarcely published research available (Castro et al., 2011). Fundamental information is needed on aspects of the production of heliconia, especially in relation to mineral nutrition (Castro et al., 2015).
Stem length and diameter, length of inflorescence, postharvest durability and carbohydrate content in flower stems are important characteristics for postharvest and commercialization of heliconia; therefore, covering the deficiencies of nitrogen, phosphorus and potassium is necessary (Castro et al., 2011). Starting the reproductive phase fertilization with nitrogen and potassium should be intensified to satisfy 
the need of the plant to ensure the vegetative growth and nutrients exported by the plant (Taniguchi et al., 2016).

As result of this study, the fertilization of N-P-K reflected an increase in the content of $\mathrm{Mg}$ and $\mathrm{Cu}$. In relation to magnesium content, the results coincide with Castro et al. (2015), these authors affirm that the rhizomes supply sufficient $\mathrm{Mg}$ to supply the plant until the beginning of flowering. The effect of magnesium on heliconia can be attributed to the number of rhizomes (18) with application of doses 93-93-93 (T493) of N-P-K. This argument can be contrasted with the results of Carvalho et al. (2012) as they obtained two to three rhizomes at 150 days in Heliconia psittacorum $x H$. spathocircinata $c v$. Golden Torch: with the control treatments, manure, N-P-K and the combination of both (manure $+\mathrm{N}-\mathrm{P}-\mathrm{K}$ ) in field conditions.

In the case of phosphorus deficiency, it can produce yellowish leaves as a result of proteolysis. Number of rhizomes is reduced, early senescence and smaller leaves occur due to the lower number of cells (Malavolta, 2006). This incident did not occur throughout this study in doses of 31-31-31 (T231) and 62-62-62 (T362) of N-P-K. During phosphate deficiency, the plant may have a greater capacity to acquire and transfer phosphate (Raghothama and Karthikeyan, 2005). The omission of $\mathrm{P}$ in heliconia does not alter the nutrients contents observed in the leaves in the vegetative phase however, it is important to consider that visual symptoms are not always observable (Castro et al., 2015).

Generally, N, P, K, Mg, Mn, S and Fe are (far more) considered in the study of heliconia (Castro et al., 2015) meanwhile the effect of copper in these plants has only a few studies on the matter. Copper is an essential metal for the normal growth and development of plants (although it is also potentially toxic); besides that, it participates in numerous physiological processes (eg. electron photosynthetic transport) however, problems arise when an excess copper is inside the cells because it inhibits the growth of plants and affects important cellular processes (Yruela, 2005). Studies show that heliconia are plants whose main characteristics are the hyperaccumulation of toxic substances and transformation of such compounds thanks to their biological properties (Peña-Salamanca et al., 2013).

According to Yruela (2005), electron photosynthetic transport has an impact on the color of the leaves. In the study conducted, the effect of copper on the leaf area and color of the plant showed no negative effects, reduced growth or toxicity. Sometimes the area of the leaf can be negatively reflected in the development of the plant, the reduction of the leaf area is involved in the process of photosynthesis; this depends on the interception of light energy and its conversion into chemical energy (Albuquerque et al., 2014).

The results of the present study lead to a main question: Why was the effect on nutrients reflected in $\mathrm{Mg}$ and $\mathrm{Cu}$ if it was fertilized with N-P-K? As mentioned above there is a cause and effect that has to do with the omission of some nutrient and the increase of another: in the same way, the substrate used has $32.2 \%$ of organic matter and this interferes in the supply of nutrients by mineralization (in particular, the release of nitrogen, phosphorus, sulfur and micronutrients available for plants) (Cepeda, 2016).

An individual heliconia plant tends to develop as a functioning rhizome system: a complex of interrelated plants in an uninterrupted export of nutrients (Castro et al., 2011). The return of the leaf blades to the cultivation area is completing a cycle around $82 \% \mathrm{~N}, 57 \% \mathrm{P}, 42 \% \mathrm{~K}, 68 \% \mathrm{Ca}$, $63 \% \mathrm{Mg}, 81 \% \mathrm{~S}, 62 \% \mathrm{Cu}, 30 \% \mathrm{Fe}, 34 \% \mathrm{Zn}, 11 \% \mathrm{Mn}$ and $53 \%$ B exported by the plant (flower stems + leaves). The availability of nutrients in this vegetable waste depends on the abiotic factors and the activity of the microorganisms in the soil (Taniguchi et al., 2016). The heliconia rhizome is a main organ for the storage of nutrients and is strongly influenced by environmental factors and nutrients available in the soil. This crop, as well as the roots and tubers, show a clear supply competition between the vegetative growth of the rhizomes and the growth of the storage tissue during some periods after the beginning of the storage growth (Castro et al., 2011). Based on this claim, heliconia fertilization management should be planned to provide sufficient amounts of nutrients to allow the rapid development of the root system and establishment of the plant in the field (Taniguchi et al., 2016).

\section{Conclusion}

The application of the different levels of fertilization with N-P-K considerably improved the vigor and color of the plant in addition to the increase of phosphorus, magnesium and copper contents of the heliconia biomass. Nevertheless, the fertilization with N-P-K did not result in any significant improvements to the growth of the heliconia in relation to the control.

\section{Author Contribution}

A.L.G. ${ }^{0000-0002-3825-5450}$ : contributed to the design of research, planting and management of plants, data collection, analysis and interpretation, writing and revision of the manuscript. A.G.P. ${ }^{0000-0001-9589-6804}$ : contributed to laboratory analysis, analysis and interpretation of data, writing and revision of the manuscript. M.A.H.C. ${ }^{0000-0002-9711-7971}$ : contributed to the design of research, planting and management of plants, data collection, analysis and interpretation, writing and revision of the manuscript. G.E.D.L. ${ }^{0000-0002-1882-4214}$ : contributed to laboratory analysis, analysis and interpretation of data, writing and revision of the manuscript. N.R.O. ${ }^{0000-0001-8694-5870}$ : contributed to the research design, data interpretation, writing and revision of the manuscript.

\section{References}

ALBUQUERQUE, A.W.; SANTOS, J.M.; FARIAS, A.P. Produtividade e qualidade pós-colheita de Helicônia Golden Torch submetida a fontes e doses de silício. Revista Brasileira de Engenharia Agrícola e Ambiental - Agriambi, v.18, n.2, p.173-179, 2014. DOI: 10.1590/ S1415-43662014000200007. 
ALBUQUERQUE, A.W.; ROCHA, E.S.; COSTA, J.P.V.; FARIAS, A.P.; BASTOS, A.L. Produção de helicônia golden torch influenciada pela adubação mineral e orgânica. Revista Brasileira de Engenharia Agricola e Ambiental, v.14, n.10, p.1052-1058, 2010. DOI: http://dx.doi. org/10.1590/S1415-43662010001000005.

ALCÁNTAR-GONZÁLEZ，G.; TREJO-TELLEZ， L.I.; FERNÁMDEZ PAVÍA, L.; N.R.M.M. Elementos esenciales. In: ALCÁNTAR-GONZÁLEZ, G.; TREJO-TÉLLEZ, L.I.C. Nutrición de cultivos. Editorial Mundi Prensa México, 2007. cap.2, p.8-43.

BECKMANN-CAVALCANTE, M.Z; AMARAL, G.C.; SILVA, A.D.S.E.; BRITO, L.P. D.S.; LIMA, A.M.N.; CAVALCANTE, Í.H.L. Nitrogen and potassium fertilization in yield and macronutrients contents of heliconia $\mathrm{cv}$. Golden Torch. Revista Brasileira de Engenharia Agrícola e Ambiental, v.20, n.4, p.337-342, 2016. DOI: 10.1590/18071929/agriambi.v20n4p337-342

CANTOR, M.; SINGUREANU, V.; DENISA, H.; ERSZEBET, B. Heliconias-Novelties and applicability in floral art. Journal of Horticulture, Forestry and Biotechnology, n.1, p.22-27, 2014.

CARVALHO, J.S.B.; MARTINS, J.D.L.; ULISSES, C.; SILVA, W.L. Adubação orgânica, mineral e organomineral e sua influencia no crescimento da helicônia em Garanhuns-PE. Horticultura Brasileira, v.30, p.579-583, 2012. DOI: http://dx.doi.org/10.1590/S0102-05362012000400003.

CASTRO, A.C.R.; ARAGÃO, F.A.S.; LOGES, V.; COSTA, A.S.; WILLADINO, L.G.; CASTRO, M.F.A.. Macronutrients contents in two development phases of Heliconia psittacorum $\times H$. spathocircinata 'Golden Torch'. Acta Horticulture, v.886, p.283-286, 2011. DOI: https://doi. org/10.17660/ActaHortic.2011.886.40.

CASTRO, A.C.R.; WILLADINO, L.G.; LOGES, V.; CASTRO, M.F.A.; ARAGÃO, F.A. S. Macronutrients deficiency in Heliconia psittacorum $x$ Heliconia spathocircinata 'Golden Torch'. Revista Ciência Agronômica, v.46, p.258-265, 2015. DOI: http://dx.doi.org/10.5935/18066690.20150005

CEPEDA, D.J. Química de suelos, 2ed. México: Editorial Trillas, 2016. 167p.

FARIAS, A.P.; ALBUQUERQUE, A.W.; FILHO, G.M.; REIS, L.S. Produtividade da Heliconia psittacorum $x$ Heliconia pathocircinada cv. Golden Torch sob diferentes fontes de adubação orgânica. Revista Brasileira de Engenharia Agricola e Ambiental, v.17, n.7, p.713-720, 2013. DOI: http://dx.doi.org/10.1590/S1415-43662013000700004.
FERREIRA, L.B.; OLIVEIRA, S.A. Estudo de doses de NPK nas variáveis de crescimento e produtividade de inflorescências de Heliconia sp. Ornamental Horticulture, v.9, n.2, p.121-127, 2003. DOI: https://doi.org/10.14295/ rbho.v9i2.175.

GARCÍA, E. Modificaciones al sistema de classificación climática de Köppen. Primera edición. México. Instuto de Geografía UNAM. 1998. 91p.

GOH, S.; LEE ABDULLAH, T.; HASSAN, S.; STANSLAS, J. Breaking dormancy and effects of shade level and NPK fertilizer rates on yield of Zingiber zerumbet (L.) Smith (Lempoyang). Agriculture, v.8, n.12, p.198, 2018. DOI: https://doi.org/10.3390/agriculture8120198.

GOWDA, J.; JAYANTHI, R.; RAJU, B. Studies on the effects of nitrogen and phosphorus on flowering in gladiolus. Current Research University of Agricultural Science, v.17, n.16, p.80-81, 1988.

JARVAN, M.; POLDMA, P. Content of plant nutrients in vegetables depending on various lime materials used for neutralising bog peat. Agronomy Research, v.2, n.1, p.39-48, 2004.

LINARES-GABRIEL，A.; LÓPEZ-COLLADO， C. J.; HERNÁNDEZ-CHONTAL, M. A.; VELASCO-VELASCO, J.; LÓPEZ-ROMERO, G. Application of soil amendments and their effect in the growth of heliconia. Ornamental Horticulture, v.24, n.3, p.7, 2018. DOI: http:// dx.doi.org/10.14295/oh.v24i3.1252

LINARES-GABRIEL， A.; LÓPEZ-COLLADO, C.J.; TINOCO-ALFARO, C.A.; VELASCO-VELASCO, J.; LÓPEZ-ROMERO, G. Application of biol, inorganic fertilizer and superabsorbent polymers in the growth of heliconia (Heliconia psittacorum cv. Tropica). Revista Chapingo. Serie Horticultura, v.23, n.1, p.35-48, 2017. DOI: 10.5154/r.rchsh.2016.02.004

MALAVOLTA, E. Manual de nutrição mineral de plantas. Piracicaba: Editora Agronômica Ceres, 2006. 631p.

VIÉGAS, I.J.M.; FERREIRA, E.R..; SILVA, D.A.S.; SILVA, S.P; CONCEIÇÃO, H.E.O.; OLIVEIRA-NETO, C.F.; MONFORT, L.E.F.; SILVA, R.T.L.; MARIANO, D.C.; OKUMURA, R.S. Growth and visual symptoms of macronutrient deficiency and zinc in Heliconia psittacorum $\mathrm{cv}$. Golden Torch. Journal of Food, Agriculture \& Environment, v.12, n.1, p.169-173, 2014.

MERIDA，D.; PIVETTA，K.F.L.; GUEDES， R.B.M.; CASTRO, C.E.F.; PURQUERIO, L. F.V. Effects of nitrogen fertilization on development, flowering, and mineral nutrition of potted Costus productus Gleason ex Maas. Journal of Plant Nutrition, v.40, n.7, p.1045-1052, 2017. DOI: $10.1080 / 01904167.2016 .1263327$ 
MUNSELL, A. Munsell color charts for plant tissues. Munsell Color Co. 1952.

PATEL, D.K.; CHAWLA, S.; AHLAWAT, T.; PATIL, S.; PATEL, M. Effect of nitrogen and phosphorus on growth, flowering and yield of bird of paradise (Strelitzia reginae) under shade net. International Journal of Chemical Studies, v.5, n.4, p.1498-1500, 2017.

PEÑA-SALAMANCA, E.J.; MADERA-PARRA, C.A.; SÁNCHEZ, J.M.; MEDINA-VÁSQUEZ, J. Bio prospección de plantas para su uso en procesos de biorremediación: caso Heliconia psittacorum (Heliconeaceae) Revista de la Academia Colombiana de Ciencias Exactas, Físicas y Naturales, v.37, n.145, p.469-481, 2013.

RAGHOTHAMA, K.G.; KARTHIKEYAN, A.S. Phosphate acquisition. Plant and Soil, v.274, n.1/2, p.37-49, 2005. Disponível em: < https:/www.jstor.org/stable/24129035 >

RUPPENTHAL, V.; CASTRO, A.M.C. Effect of urban waste compost on nutrition and yield of gladiolus. Revista Brasileira de Ciência do Solo, v.29, n.1, p.145-150, 2005. ISSN 0100-0683. DOI: http://dx.doi.org/10.1590/S010006832005000100016.

SAS. Statistical Analysis System Cary, N.C. USA 2014.
STEWART, W.; DIBB, D.; JOHNSTON, A.; SMYTH, T. The contribution of commercial fertilizer nutrients to food production. Agronomy Journal, v.97, n.1, p.1-6, 2005. ISSN 1435-0645. DOI: 10.2134/agronj2005.0001.

SUSHMA, H.; REDDY, B.; KULKARNI, B.; PATIL, C. Effect of spacing and inorganic nutrients on growth, flowering and nutrient status in heliconia (Heliconia sp.). Karnataka Journal of Agricultural Sciences, v.25, n.4, 2013.

TANIGUCHI, C.A.K.; CASTRO, A.C.R.; SILVA, T.F.; SILVA, E.B.; MARTINS, T.S. Growth, nutrient accumulation and export by Heliconia 'Red Opal'. Ornamental Horticulture, v.22, n.3, p.335-342, 2016. DOI: https://doi. org/10.14295/oh.v22i3.954

TIMILSENA, Y.P.; ADHIKARI, R.; CASEY, P.; MUSTER, T.; GILL, H.; ADHIKARI, B. Enhanced efficiency fertilisers: a review of formulation and nutrient release patterns. Journal of the Science of Food and Agriculture, v.95, n.6, p.1131-1142, 2015. DOI: https://doi.org/10.1002/ jsfa.6812.

YRUELA, I. Copper in plants. Brazilian Journal of Plant Physiology, v.17, n.1, p.145-156, 2005. ISSN 1677-0420. DOI: http://dx.doi.org/10.1590/S167704202005000100012. 